\title{
Reverse phase high-performance liquid chromatography for quantification of hydroxymethylnitrofurazone in polymeric nanoparticles
}

\author{
Lis Marie Monteiro ${ }^{1}$, Guilherme Diniz Tavares ${ }^{2}$, Elizabeth Igne Ferreira ${ }^{1}$, Vladi Olga Consiglieri ${ }^{1}$, \\ Nadia Araci Bou-Chacra, ${ }^{1, *}$, Raimar Löbenberg ${ }^{3}$
}

\author{
${ }^{1}$ Departmento de Farmácia, Faculdade de Farmácia, Universidade de São Paulo, São Paulo, SP, Brazil, ${ }^{2}$ Departamento de \\ Ciências Farmacêuticas, Faculdade de Farmácia, Universidade Federal de Juiz de Fora, Juiz de Fora, MG, Brazil, ${ }^{3}$ Faculty \\ of Pharmacy and Pharmaceutical Sciences, University of Alberta, Edmonton, Alberta, Canadá
}

\begin{abstract}
Hydroxymethylnitrofurazone (NFOH) is a new compound with potential leishmanicidal and trypanocidal activity. Despite its effectiveness, the formulators have to overcome its poor aqueous solubility. Recently, polymeric nano-scale drug delivery systems have proposed for the treatment of neglected diseases. As several studies have confirmed the advantages of such formulations, and this approach provides new analytical challenges, including the need to detect trace amounts of the drug. A suitable method was developed and validated for NFOH determination bound to poly ( $n$-butylcyanoacrylate) (PBCA) nanoparticles. The chromatographic separation was achieved using a $\mathrm{C} 18$ column maintained at $25^{\circ} \mathrm{C}$ and an isocratic mobile phase consisting of water and acetonitrile: 80:20 (v/v) at a flow rate of $1.2 \mathrm{~mL}$ $\mathrm{min}^{-1}$ and UV-detection at $265 \mathrm{~nm}$. Investigated validation parameters included selectivity, linearity, accuracy, precision and robustness (changes in column temperature, mobile phase composition and flow). The method was specific, the peak of NFOH had no interference with any nanoparticle excipients and no co-elution with main degradation product (nitrofurazone). Linearity was over the range of $\left.0.94-13.11 \mu \mathrm{g} \mathrm{mL}-1 \mathrm{r}^{2}=0.999\right)$. The method was accurate and precise, recovery of $100.7 \%$, RSD of $0.4 \%$; intra-day and inter-day RSD range $9.98-9.99 \mu \mathrm{g} \mathrm{mL}^{-1}$ and $0.3 \%$ to $0.5 \%$, respectively. Robustness confirmed that method could resist the applied changes. Application of the optimized method revealed an encapsulation efficiency of $64.4 \%(n=3)$. Therefore, the method was successfully developed and validated for the determination of the encapsulation efficiency of NFOH-PBCA nanoparticles.
\end{abstract}

Uniterms: Hydroxymethylnitrofurazone/determinação. Nanoparticle. High-performance liquid chromatography/reverse phase/quantitative analysis. Poly(n-butylcyanoacrylate)/nanoparticles/ encapsulation.

Hidroximetilnitrofural (NFOH) é um novo composto que possui atividade leishmanicida e tripanomicida potencial. Um método apropriado foi desenvolvido e validado para a determinação de $\mathrm{NFOH}$ em nanopartículas de poli( $n$-butil cianoacrilato) (PBCA). A separação cromatográfica foi obtida usando uma coluna C18 (5 $\mu \mathrm{m}$ de tamanho de partícula, 4,6 $\mathrm{mm}$ de diâmetro e $150 \mathrm{~mm}$ de comprimento), mantida a $25^{\circ} \mathrm{C}$, fase móvel composta de água e acetonitrila 80:20 (v/v), fluxo de $1,2 \mathrm{~mL} \mathrm{~min}{ }^{-1}$ e detecção por UV a $265 \mathrm{~nm}$. Investigaram-se os seguintes parâmetros de validação: seletividade, linearidade, exatidão, precisão e robustez (mudanças na temperatura de coluna, proporção da fase móvel e fluxo). O método mostrou-se específico, o pico de NFOH não apresentou interferência dos picos provenientes dos excipientes das nanopartículas e separado do principal produto de degradação (nitrofural). A linearidade foi obtida na faixa de $0,94-13,11 \mu \mathrm{g} \mathrm{mL} \mathrm{m}^{-1}\left(\mathrm{r}^{2}=0,999\right)$. O método mostrou exatidão (recuperação de $100,7 \%$, DPR de 0,4 \%) e precisão (intra-dia e inter-dia, 9,98-9,99 $\mu \mathrm{g} \mathrm{mL}^{-1}$ e DPR 0,3\% a 0,5\%, respectivamente). A robustez provou que o método pode resistir às mudanças propostas. Aplicação do método otimizado revelou eficiência de encapsulação de $64,4 \%(n=3)$. Portanto, o método foi desenvolvido e validado com sucesso para a determinação da eficiência de encapsulação de nanopartículas de NFOH-PBCA.

Unitermos: Hidroximetilnitrofural/determinação. Nanopartículas. Cromatografia líquida de alta eficiência/fase reversa/análise quantitativa. Poli(n-butilcianoacrilato)/nanopartículas/encapsulação.

*Correspondence: N. A. Bou-Chacra. Departamento de Farmácia. Faculdade de Ciências Farmacêuticas. Universidade de São Paulo. Av. Prof. Lineu Prestes, 580 - 05508-900 - São Paulo - SP, Brasil. E-mail: chacra@usp.br 


\section{INTRODUCTION}

The hydroxymethylnitrofurazone (NFOH) (Figure 1) is a new compound with potential use to treat two neglected tropical diseases (NTDs): Chagas' disease (Chung et al., 2003) and leishmaniasis. The treatment of both diseases requires parenteral administration for a prolonged period, causing severe adverse effects, such as cardiac, renal, pancreatic and liver impairment (World Health Organization, 2010; Schlossberg, 2008).

Chung and colleagues first obtained the $\mathrm{NFOH}$ using a molecular modification from its parent compound nitrofurazone (NF). The NFOH showed high activity in cell cultures infected with Trypanosoma cruzi and significant less toxicity than NF (Chung et al., 2003). Our group, using L. amazonensis, confirmed NFOH in vitro activity against Leishmania sp. Both parasites have similar metabolism and they belong to the same family: Trypanosomatidae (order Kinetoplastida) (Teixeira et al., 2012). Despite its effectiveness, the formulators have to overcome its poor aqueous solubility (Grillo et al., 2008) aiming for the development of a new generation of antileismaniasis medicines. In this sense, nano-scale drug delivery systems can enable such medicines. This approach might have remarkable advantages over conventional formulations such as improving component solubility, enhancement of bioavailability, reducing dose, achieving constant therapeutic levels over an extend period of time, enhancement of stability and protection from physical and chemical degradation, among others (Bamrungsap et al., 2012; Faraji, Wipf, 2009; Parveen, Misra, Sahoo, 2012; Singh, Lillard Jr, 2009).

As several studies have confirmed, such formulations provide new analytical challenges, including the need to detect small amounts of drug. A significant number of techniques, especially high-performance liquid chromatography (HPLC) are described for the quantification of drug encapsulation in PBCA nanoparticles (Shabir et al., 2007).

To the best of our knowledge, no previous reports exist in the literature outlining the concurrently development and validation of an HPLC method for the quantification of NFOH encapsulated with polymeric nanoparticles. Grillo et al. (2008) described a HPLC method for quantification of free $\mathrm{NFOH}$ and in an inclusion complex of $\mathrm{NFOH}$ and $\beta$-cyclodextrin. When this method was applied to NFOH-PBCA nanoparticles, one low response peak near the void volume time was found for all samples. These preliminary results showed the inadequacy of this method for the quantification of $\mathrm{NFOH}$ in PBCA. In the present work, we describe the development, validation and application of an analytical reversedphase HPLC-UV method for the specific quantification of hydroxymethylnitrofurazone encapsulated in poly (n-butylcyanoacrylate) nanoparticles.

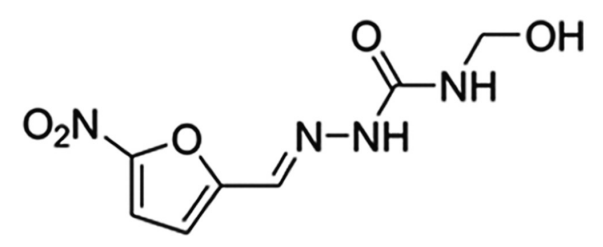

FIGURE 1 - Chemical structure of NFOH.

\section{MATERIAL AND METHODS}

\section{Chemical and reagents}

PBCA nanoparticles loaded with NFOH were obtained by emulsion polymerization as previously described (Tavares et al., 2011; Sham et al., 2004). Prof. Elizabeth Igne Ferreira, from FCF-USP (São Paulo, Brazil) provided hydroxymethylnitrofurazone from LAPEN (Laboratory of Design and Synthesis of Chemotherapeutic Agents Potentially Active on Neglected Diseases). The cyanoacrylate monomer was purchased from B. Braun Laboratories (Tuttlingen, Baden-Württemberg, Germany) and dextran 70 from Sigma-Aldrich Corporation (St Louis, MO, USA). HPLC-grade acetonitrile was acquired from EMD Chemicals Inc. (USA) and purified water from Milli-Q system (Millipore). All other chemicals and solvents were at least analytical grade.

\section{Apparatus and chromatographic conditions}

The chromatographic system was a Waters Alliance 2695 , equipped with a quaternary pump, a diode array detector and an automatic injector. For data collection and calculation, Empower 3 software was used. The analysis was performed under isocratic elution, using a Hypersyl Column, C18, $5 \mu \mathrm{m}$ particle size, 4.6 X150 mm (Thermo, Waltham, MA, EUA), the improved mobile phase was composed of water and acetonitrile at a ratio 80:20 (v/v) maintained at $25^{\circ} \mathrm{C}$. Measurements were performed at $265 \mathrm{~nm}$ at a flow rate $1.2 \mathrm{~mL} \mathrm{~min}^{-1}$ with an injection volume of $20 \mu \mathrm{L}$. The NFOH peak was confirmed by its characteristic retention time of 4.9 minutes and spectrum.

\section{Sample, standard solution and system suitability preparation}

The sample solution for quantification of the 
encapsulated compound was prepared transferring an aliquot of nanoparticles to an Eppendorf tube and centrifuged at $16.800 \mathrm{RFC}(\mathrm{x} \mathrm{g}) 60$ minutes, $25^{\circ} \mathrm{C}$. The supernatant was filtered with $0.45 \mu \mathrm{m}$ pore size PVDF-membrane (Millipore, Barcelona) and used for measurements. Unloaded nanoparticles solution was prepared transferring an aliquot of $1.0 \mathrm{~mL}$ of the PBCA nanoparticles suspension without $\mathrm{NFOH}$ to a $100 \mathrm{~mL}$ volumetric flask added with mobile phase.

NFOH and NF standard stock solution $\left(200 \mu \mathrm{g} \mathrm{mL}{ }^{-1}\right.$,

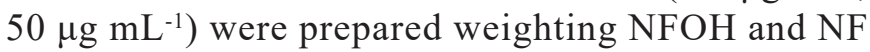
accurately and dissolving them, separately, in acetonitrile. $\mathrm{NFOH}$ standard solution $\left(10 \mu \mathrm{g} \mathrm{mL}^{-1}\right)$ was prepared from the NFOH stock solution, using mobile phase as diluent. System suitability solution (NFOH $10 \mu \mathrm{gL}^{-1}$, $\mathrm{NF} 1 \mu \mathrm{g} \mathrm{mL}^{-1}$ ) was prepared diluting the NFOH and NF stock solutions together with mobile phase.

Before injecting the solutions, the following parameters were evaluated: resolution between $\mathrm{NFOH}$ and $\mathrm{NF}$ at least 2.0, the NFOH asymmetry peak less than 1.5 , theoretical plates more or equal than 2000 and $\mathrm{NFOH}$ retention time of $4.9 \pm 0.5$ minutes.

\section{Method development}

Grillo et al.(2008) method was modified and the adjustments provided proper separation of NFOH from NF (main hydrolysis degradation product) and from the nanoparticle excipients. Additionally, the improved response made it possible to assess diluted solutions, since high encapsulation efficiency was expected (low amounts of NFOH in the supernatant).

\section{Validation study}

The validation process was performed according to the guideline outlined in The International Conference on Harmonization of Technical Requirements for Registration of Pharmaceuticals for Human Use. Quality Guidelines. Analytical Validation Q2. Q2 (R1) validation of analytical procedures: text and methodology (ICH, 2005).

\section{Selectivity}

The selectivity of the method was evaluated in four different solutions: unloaded nanoparticle solution, nanostructured NFOH sample, mobile phase and standard NFOH. Spectral homogeneity was evaluated for all NFOH peaks in order to verify the absence of co-elution of NFOH, NF and nanoparticle excipients.

\section{Linearity}

Linearity was evaluated using six NFOH standard solutions of $1.0,4.0,8.0,10.0,12.0$ and $14.0 \mu \mathrm{g} \mathrm{mL}-1$ added to unloaded nanoparticles. Each solution was prepared in three replicates. The experimental results were graphically plotted, obtaining a calibration curve and calculating y-intercept, slope, VIF (variance inflation factor), correlation coefficients (r) and determination $\left(\mathrm{r}^{2}\right)$, lack of fit test, PRESS (prediction sum of squares), standard deviation and Durbin -Watson statistic using Minitab ${ }^{\circledR} 16$ and GraphPad Prim ${ }^{\circledR} 6$.

\section{Precision}

The precision was assessed by testing the repeatability of six sample solutions once on the same day (intra-day), and on a different day (inter-day). The two-sample $t$-test was applied to compare the means.

\section{Accuracy}

The recovery studies were conducted at three different levels of standard NFOH added with unloaded nanoparticles. The samples were prepared accordingly to the "sample preparation," and the theoretical drug concentrations of $1.0,10.0$, and $14.0 \mu \mathrm{g} \mathrm{mL}^{-1}$ were prepared in three replicates each. The method accuracy was expressed as the average recovery and relative standard deviation (RSD).

\section{Robustness}

The robustness was evaluated using six replicates prepared according to the sample preparation described previously. The following variations were selected: column temperature $\left(20\right.$ to $\left.30^{\circ} \mathrm{C}\right)$, mobile phase $(75: 25$ and $85: 15$, water and acetonitrile), flow (1.1 and $\left.1.3 \mathrm{~mL} \mathrm{~min}^{-1}\right)$. The statistical evaluation was performed using ANOVA, after assuming the normality and equal variance of the data.

\section{PBCA nanoparticles encapsulation efficiency (EE\%)}

In literature, the EE of nanoparticles or microspheres is generally determined in an indirect way (Cournarie et al., 2004). The amount of drug encapsulated in nanoparticles was determined by the difference between the total amounts of drug and the entrapped drug after ultracentrifugation (Equation 1). 


$$
\mathrm{EE} \%=\frac{\left(\begin{array}{c}
\text { total amount } \\
\text { of drug }
\end{array}\right)-\left(\begin{array}{c}
\text { drug recovered } \\
\text { from supernatant }
\end{array}\right)}{\text { total amount of drug }} \times 100
$$

\section{RESULTS AND DISCUSSION}

\section{Method development and optimization}

Initially the samples were analyzed using a mobile phase consisting of water: acetonitrile $(20: 80, \mathrm{v} / \mathrm{v})$ as proposed by Grillo et al. (2008). Under these conditions, the resolution and peak symmetry were not acceptable. Therefore, an alternative mobile phase was investigated. After testing several proportions, the final composition was water: acetonitrile $(80: 20, \mathrm{v} / \mathrm{v})$, under which a sharp peaks with suitable resolution of $\mathrm{NFOH}$ and $\mathrm{NF}(\mathrm{R} \geq 2.0)$ were obtained (Figure 3D).

Although the peaks were well separated and symmetric, the NFOH peak height could not reach 0.04 $\mathrm{AU}$, even when $50 \mu \mathrm{L}$ were injected, the response was not improved and the NFOH and NF peaks were co-eluted. Further, the NFOH peak spectrum (Figure 2) revealed the wavelength could be altered from $\lambda=210 \mathrm{~nm}$ (as proposed by Grillo et al., 2008) to maximum absorbance $\lambda(\lambda=265 \mathrm{~nm})$. When applying the wavelength of $265 \mathrm{~nm}$, the nanostructured NFOH sample reached 0.08AU. Thus, this wavelength was chosen as the best chromatographic response for this work.

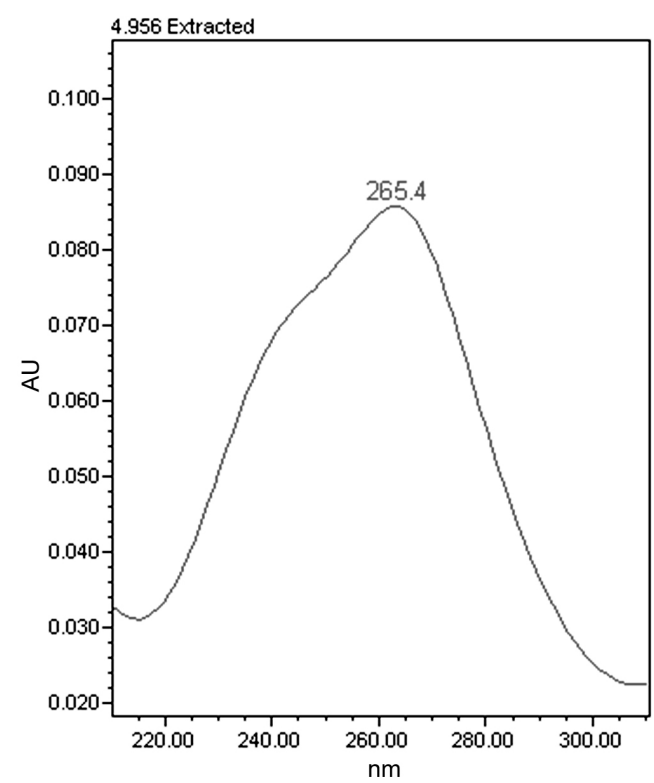

FIGURE 2 - Hydroxymethylnitrofurazone spectrum. Chromatographic conditions: mobile phase water and acetonitrile $80: 20(\mathrm{v} / \mathrm{v})$, flow of $1.2 \mathrm{~mL} \mathrm{~min}^{-1}$, injection volume of $20 \mu \mathrm{L}$, column temperature of $25^{\circ} \mathrm{C}$.

\section{Method validation}

\section{Selectivity}

As recommended by ICH Q2(R1), a chromatographic method is considered selective when each peak within the chromatogram corresponds to only one substance (peak purity evaluation). In present work DAD analysis revealed peak purity for all NFOH samples.

Moreover, a mixture of NFOH and NF standards and nanostructured NFOH samples chromatograms did not show any interferences (Figure 3). Likewise, unloaded nanoparticles and the mobile phase revealed no peak around NFOH retention time (4.9 min) (Figure 3).

Therefore, the optimized method revealed itself selective for the quantification of NFOH.

\section{Linearity}

Although the method which has a correlation coefficient (r) greater than 0,99 can be accepted as linear, other statistics should be used to determine the quality of fit of the calibration curve, for example, the DurbinWatson statistic and the lack of fit test (Loco et al., 2002). The statistics presented in Table I exposes the linear characteristic of the method. With regard to the coefficients of determination and correlation, these were 0.999 and 0.9999 , respectively. These values, close to 1 , and the results obtained for the test of lack of fit ( $p$-value $>0.1 ; \alpha=0.05$ ) and the Durbin-Watson statistic (2.03826), indicate the suitability of proposed linear model. Additionally, the value of 1.00 for the variance inflation factor (VIF) showed the absence of multicollinearity. With regard to the PRESS statistic, the value was equal to 0.767 and therefore considered adequate (value <1.0) (Montgomery, Peck, Vining, 2001).

\section{Precision}

The measurement precision was evaluated by performing six replicate samples of nanostructured $\mathrm{NFOH}$ at $100 \%$ of the method concentration $\left(10 \mu \mathrm{g} \mathrm{mL}^{-1}\right)$ in the same day (intra-day) and after 2 days (inter-day). For intraday analysis the precision was $0.34 \%$; as for inter-day, CV was $0.49 \%$, (Table II) which complies with the acceptance criteria proposed by the ICH Q2(R1) $(\mathrm{CV}<2.0 \%)$. The $p$-value of the two-sample t-test was $0.692(\alpha=0.05)$, which means that the null hypothesis was accepted. Thus, these values have no significant difference between their means. Therefore, these results indicate that the proposed method presented adequate precision.

\section{Accuracy}

The average recoveries percentage of the spiked 

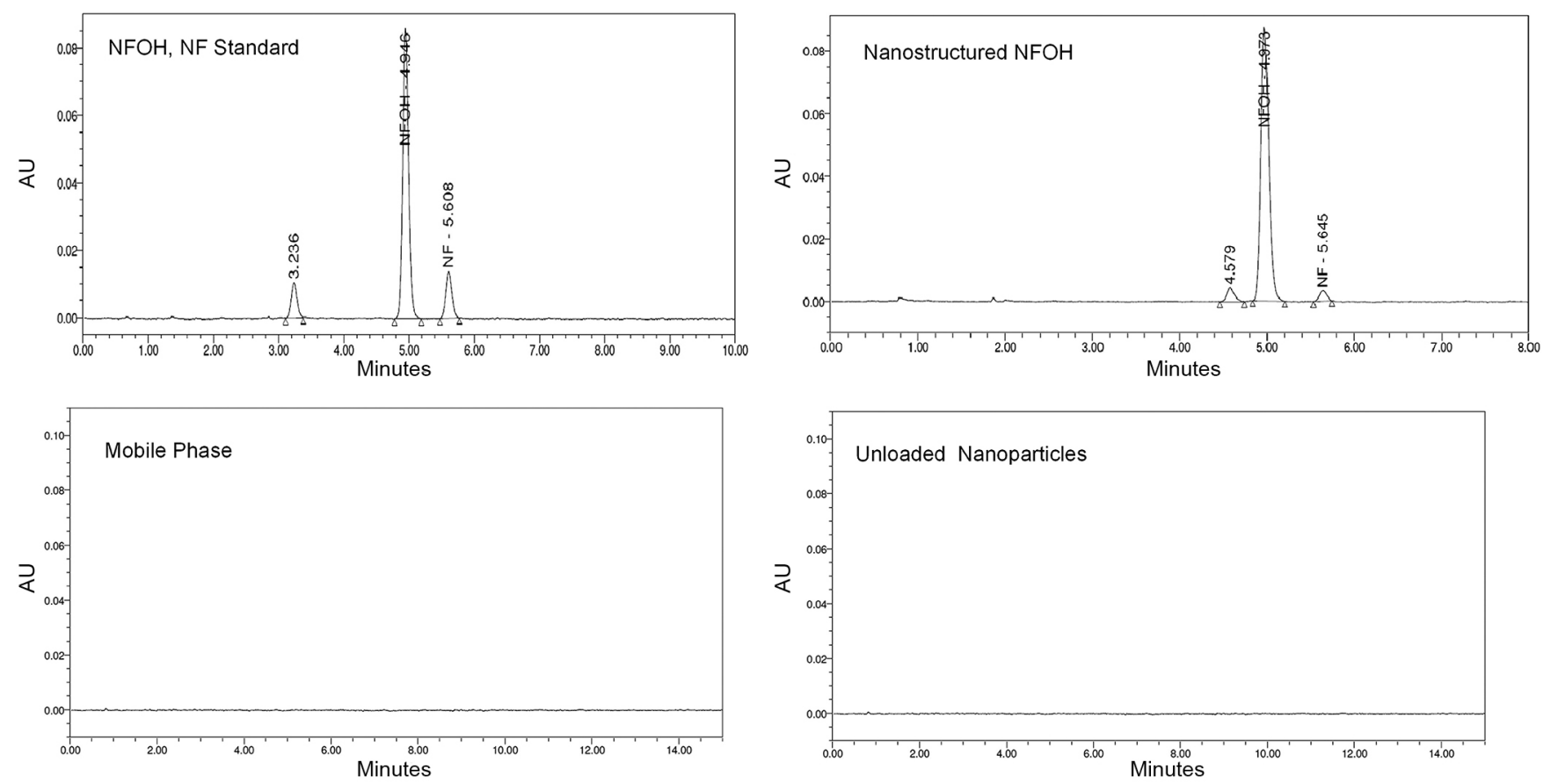

FIGURE 3 - Selectivity chromatograms. Mobile phase: water and acetonitrile 80:20 (v/v), flow: $1.2 \mathrm{~mL} \mathrm{~min}^{-1}, \lambda$ : UV $265 \mathrm{~nm}$, injection volume: $20 \mu \mathrm{L}$, column temperature: $25^{\circ} \mathrm{C}$. NFOH: hydroxymethylnitrofurazone, NF: nitrofurazone.

TABLE I - Statistical analysis evaluation of the linear regression, $\mathrm{N}=3$

\begin{tabular}{lc}
\hline Statistical & $\begin{array}{c}\text { Regression } \\
\text { Analysis }\end{array}$ \\
\hline Slope & 57254 \\
Intercept & -3265 \\
Coefficient of correlation (r) & 0,9999 \\
VIF (variance inflation factor) & 1.000 \\
Coefficient of determination $\left(\mathrm{r}^{2}\right)$ & 0.9990 \\
Durbin - Watson & 2,0355 \\
Lack of fit & p-value $>0.1$ \\
PRESS (prediction sum of squares) & 0.0767 \\
Standard deviation & 0.0453 \\
\hline
\end{tabular}

TABLE II - Precision results for different levels of nanostructured $\mathrm{NFOH}$

\begin{tabular}{lcc}
\hline Precision & $\begin{array}{c}\text { NFOH } \\
\text { concentration } \\
\left(\mu \mathrm{g} \mathrm{mL}^{-1}\right)^{*}\end{array}$ & Two-Sample t-test \\
\hline Intra-day & 9.98 & p- value 0.692 \\
$\mathrm{CV}(\%)$ & 0.34 & \\
Inter-day & 9.99 & \\
$\mathrm{CV}(\%)$ & 0.49 & \\
\hline
\end{tabular}

*Expressed as the mean of six replicates
NFOH was $100.7 \%$, while $\%$ RSD value was $0.6 \%$ (Table 4) indicating accuracy of the reported method, once it met the acceptance ICH Q2(R1) criteria $(\mathrm{RSD}<2 \%)$.

\section{Robustness}

Minor deliberate changes in different experimental parameters did not significantly affect the recoveries (Table IV). This outcome was confirmed when the mean values were compared through ANOVA. The null hypothesis was accepted ( $p$-value equal to $0.053, \alpha=0.05$ ). Therefore, no significant difference between means was found, reiterating the method robustness.

\section{Method application}

\section{Encapsulation efficiency (EE)}

The application of the proposed method for the quantification of NFOH in PBCA nanoparticles revealed encapsulation efficiency of $\mathrm{NFOH}$ in $\mathrm{PBCA}$ nanoparticles of 64.4 RSD $0.4 \%(n=3)$. No alterations in the chromatograms or unusual peaks were observed during validation.

\section{CONCLUSION}

A RP-HPLC method was successfully developed and validated for the quantification of $\mathrm{NFOH}$ bound to PBCA nanoparticles. The described method has no 
TABLE III - Accuracy results for different levels of NFOH in standard solutions

\begin{tabular}{lcccc}
\hline & $\begin{array}{c}\text { Amount added } \\
\left(\mu \mathrm{g} \mathrm{mL}^{-1}\right)^{*}\end{array}$ & $\begin{array}{c}\text { Amount recovered } \\
(\mu \mathrm{g} \mathrm{mL})^{*}\end{array}$ & $\begin{array}{c}\text { Recovery } \\
(\%)^{*}\end{array}$ & $\begin{array}{c}\text { Average Recovery } \\
(\%)\end{array}$ \\
\hline $\mathrm{NFOH}$ & 0.9363 & 0.9372 & 100.1 & 100.7 \\
& 9.3633 & 9.4476 & 100.9 & RSD 0.6 \\
\hline
\end{tabular}

*Expressed as the mean of three replicates

TABLE IV - Variations in the chromatographic conditions evaluation the robustness

\begin{tabular}{lcc}
\hline Condition & Mean (\%) & RSD (\%) \\
\hline Initial & 100.3 & 0.3 \\
Water acetonitrile 75:25 & 100.7 & 0.2 \\
Water acetonitrile 85:15 & 100.7 & 0.2 \\
Flow $1.1 \mathrm{~mL} \mathrm{~min}^{-1}$ & 100.8 & 0.2 \\
Flow $1.3 \mathrm{~mL} \mathrm{~min}^{-1}$ & 100.7 & 0.3 \\
Column $20^{\circ} \mathrm{C}$ & 100.7 & 0.2 \\
Column $30^{\circ} \mathrm{C}$ & 100.5 & 0.2 \\
\hline
\end{tabular}

interference from excipients, allowing the quantification of NFOH in these formulations with highy accuracy. The method revealed to be simple, accurate and precise and could be easily applied in the determination of NFOH and its main degradation product when used with nanoparticles as drug carrier.

\section{ACKNOWLEDGMENTS}

The authors are grateful to CNPq (National Council for Scientific and Technological Development) for financial support and to United States Pharmacopeia (Tamboré, Brazil), for material, equipment and installations.

\section{REFERENCES}

BAMRUNGSAP, S.; ZHAO, Z.; CHEN, T.; WANG, L.; LI, C.; FU, T.; TAN, W. Nanotechnology in therapeutics: a focus on nanoparticles as a drug delivery system. Nanomedicine (London), v.7, n.8, p.1253-1271, 2012.

CHUNG, M.C.; GÜIDO, R.V.; MARTINELLI, T.F.; GONÇALVES, M.F.; POLLI, M.C.; BOTELHO, K.C.; VARANDA, E.A.; COLLI, W.; MIRANDA, M.T.; FERREIRA, E.I. Synthesis and in Vitro evaluation of potential antichagasic hydroxymethylnitrofurazone (NFOH-121): a new nitrofurazone prodrug. Bioorg. Med. Chem., v.11, n.22, p.4779-4783, 2003.
COURNARIE, F.; CHERON, M.; BESNARD, M.; VAUTHIER, C. Evidence for restrictive parameters in formulation of insulin-loaded nanocapsules. Eur. J. Pharm. Biopharm., v.57, n.2, p.171-179, 2004.

FARAJI, A.H.; WIPF, P. Nanoparticles in cellular drug delivery. Bioorg. Med. Chem., v.17, n.8, p.2950-2962, 2009.

ICH. International conference on harmonisation of technical requirements for registration of pharmaceuticals for human use. Quality Guideline. View All Quality Guidelines. Analytical Validation Q2. Q2 (R1) - validation of analytical procedures: text and methodology. S.1.: ICH, 2005. Available at: $<$ http://www.ich.org/fileadmin/Public_Web_ Site/ICH_Products/Guidelines/Quality/Q2_R1/Step4/ Q2_R1_Guideline.pdf $>$. Accessed on: 23 Jan. 2012.

GRILLO, R.; DE MELO, N.F.; MORAES, C.M.; DE LIMA, R.; MENEZES, C.M.; FERREIRA, E.I.; ROSA, A.H.; FRACETO, L.F. Study of the interaction between hydroxymethylnitrofurazone and 2-hydroxypropyl-betacyclodextrin. J. Pharm. Biomed. Anal., v.47, n.2, p.295302, 2008.

LOPES, R.; ELEUTÉRIO, C.V.; GONÇALVES, L.M.D.; CRUZ, M.E.M.; ALMEIDA, A.J. Lipid nanoparticles containing oryzalin for the treatment of leishmaniasis. Eur. J. Pharm. Sci., v.45, n.4, p.442-450, 2012.

LOCO, J.V.; ELSKENS, M.; CROUX, C.; BEERNAERT, H. Linearity of calibration curves: use and misuse of the correlation coefficient. Accred. Qual. Assur., v.7, p.281285, 2002.

MONTGOMERY, D.C.; PECK, E.A.; VINING, G.G. Introduction to linear regression analysis. 3.ed. New York: Wiley, 2001. $612 \mathrm{p}$.

PARVEEN, S.; MISRA, R.; SAHOO, S.K. Nanoparticles: a boon to drug delivery, therapeutics, diagnostics and imaging. Nanomedicine, v.8, n.2, p.147-166, 2012. 
SCHLOSSBERG, D. Clinical infectious disease. 1ed. New York: Cambridge University Press, 2008. 1392 p.

SHABIR, G.A.; LOUGH, J.W.; ARAIN, S.A.; BRADSHAW, T.K. Evaluation and application of best practice in analytical method validation. J. Liq. Chromatogr. Relat. Technol., v.30, n.3, p.311-333, 2007.

SHAM, J.O.; ZHANG, Y.; FINLAY, W.H.; ROA, W.H.; LOBENBERG, R. Formulation and characterization of spray-dried powders containing nanoparticles for aerosol delivery to the lung. Int. J. Pharm., v.28, n.269, p.457-467, 2004.

SINGH, R.; LILLARD JR, J.W. Nanoparticle-based targeted drug delivery. Exp. Mol. Pathol., v.86, n.3, p.215-223, 2009.

TAVARES, G.M.; ISHIKAWA, G.M.; MONTEIRO, T.F.; ZANOLINI, C.; KEDOR-HACKMANN, E.R.M.; BOU-CHACRA, N.A.; CONSIGLIERI, V.O. Derivative spectrophotometric method for determination of acyclovir in polymeric nanoparticles. Quím. Nova, v.35, n.1, p.203206, 2011.
TEIXEIRA, S.M.; PAIVA, R.M.C.; KANGUSSUMARCOLINO, M.M.; ROCHA, W. Trypanosomatid comparative genomics: contributions to the study of parasite biology and different parasitic diseases. Genet. Mol. Biol., v.35, n.1, p.1-17, 2012.

WORLD HEALTH ORGANIZATION. WHO. Control of the Leishmaniasis: report of a meeting of the WHO expert committee on the control of leishmaniases. Geneva: WHO, 2010. 186 p. (WHO technical report series, 949).

Received for publication on $04^{\text {th }}$ June 2014 Accepted for publication on $29^{\text {th }}$ July 2015 
